\title{
Effects of habitat fragmentation per se on decapods and fishes inhabiting seagrass meadows in the northern Gulf of Mexico
}

\author{
Matthew W. Johnson ${ }^{1,2, *}$, Kenneth L. Heck Jr. ${ }^{1,2}$ \\ ${ }^{1}$ Dauphin Island Sea Laboratory, 101 Bienville Boulevard, Dauphin Island, Alabama 36528, USA \\ ${ }^{2}$ Department of Marine Sciences, University of South Alabama, Mobile, Alabama 36688, USA
}

\begin{abstract}
The role of habitat fragmentation per se on ecological processes is incompletely understood in marine environments. Previous work in fragmented habitats has concentrated on growth of bivalve species, faunal abundances and predation of tethered crabs. Unlike other studies, in the present study we measured abundances of decapods and fishes and estimated secondary production from in situ sampling of multiple sized, naturally occurring seagrass beds and artificial seagrass units (ASUs). In 2 locations (Thalassia testudinum meadows in Big Lagoon, Florida, and Halodule wrightii meadows in Grand Bay, Alabama), we sampled 7 to 10 seagrass patches ranging in size from $<1$ to $>100 \mathrm{~m}^{2}$ at 2 mo intervals between June and October 2001. We also sampled 10 replicate ASUs of 2 shapes (stellate and circular) and 2 sizes $\left(0.2036\right.$ and $\left.0.0487 \mathrm{~m}^{2}\right)$ that were colonized for $4 \mathrm{wk}$ at both locations in June, August and October. Our results indicated that patch size, patch shape, intra-patch location, and degree of isolation can each influence macrofaunal community structure and secondary production estimates; however, their overall impact was inconsistent. Our data suggest that the effects of habitat fragmentation are location-, time- and species-specific, and that fragmentation at this scale may have little impact on faunal assemblages of seagrass meadows.
\end{abstract}

KEY WORDS: Halodule wrightii · Artificial seagrass units · Secondary production · Thalassia testudinum $\cdot$ Abundance

\section{INTRODUCTION}

Habitat fragmentation per se, or fragmentation without loss of area, is a common occurrence in many terrestrial (reviews by Andrén 1994, Bender et al. 1998, Debinski \& Holt 2000) and marine (Fonseca \& Bell 1998) environments, and can lead to a reduction in patch size, an increase in patch perimeter inter-patch distance and in perimeter:area ratio, as well as an overall alteration of patch configuration (Trzcinski 1999, Villard et al. 1999). Typically, marine habitats are comprised of discrete patches of varying size. Often, a seagrass meadow is a mosaic of vegetated patches interspersed with patches of unvegetated substrate (Larkum \& den Hartog 1989, Robbins \& Bell 1994, Bell et al. 1995). Although seagrass cover may approach $100 \%$ in some areas, numerous natural disturbances such as waves and episodic storms prevent continuous seagrass coverage (reviewed by Fonseca et al. 1998). In addition, human-induced seagrass loss resulting from activities such as dredging, eutrophication, disease, and damage from boating has increased dramatically in recent decades (Orth et al. 1984, Duarte 1995, Sargent et al. 1995). Existing submerged aquatic vegetation (SAV) habitats have been reduced in size and increasingly fragmented, increasing the likelihood that seagrass-associated macrofauna may be susceptible to these changes.

In perhaps the earliest paper available on this topic, McNeill \& Fairweather (1993) found conflicting results between experiments with natural SAV and artificial seagrass units (ASU) that were both employed to test whether a single large or several small plots of the 
same total area (the SLOSS argument: see Ovaskainen [2002] and Peintinger et al. [2003] for debate) supported more species of benthic invertebrates and fishes. In natural SAV, several small beds supported significantly more species than a single large bed, while the results of the ASU experiments were equivocal. A study that compared bivalve abundances at the edges and in the interiors of seagrass beds (Bologna 1998, Bologna \& Heck 2000) found greater macroinvertebrate abundance and secondary production at SAV bed edges than in bed interiors, even though plant biomass and shoot density (which are usually reported to be positively correlated with animal abundance) were lower at the edges than in the interiors. In addition, changing patch dynamics may influence (albeit inconsistently) many ecological processes including community structure (Bell et al. 2001), predation (Irlandi 1997, Hovel \& Lipcius 2002), colonization (Eggleston et al. 1998, 1999) and settlement (Bologna \& Heck 2000). To date, the only conclusion that can be drawn from recent habitat fragmentation research is that much more remains to be done to understand the effects of habitat size and shape as they influence biotic interactions in seagrass dominated habitats.

We know from a variety of studies in different types of environments that the ratios of 'edge' to interior (i.e. perimeter to area ratios, $\mathrm{P}: \mathrm{A}$ ) can determine rates of exchange of nutrients, food and organisms between habitats (see review by Polis et al. 1997). Unlike terrestrial literature, there is little available information that addresses how patch size, shape, inter-patch distance, or position within the patch influence the structure and function of seagrass beds or other marine habitats
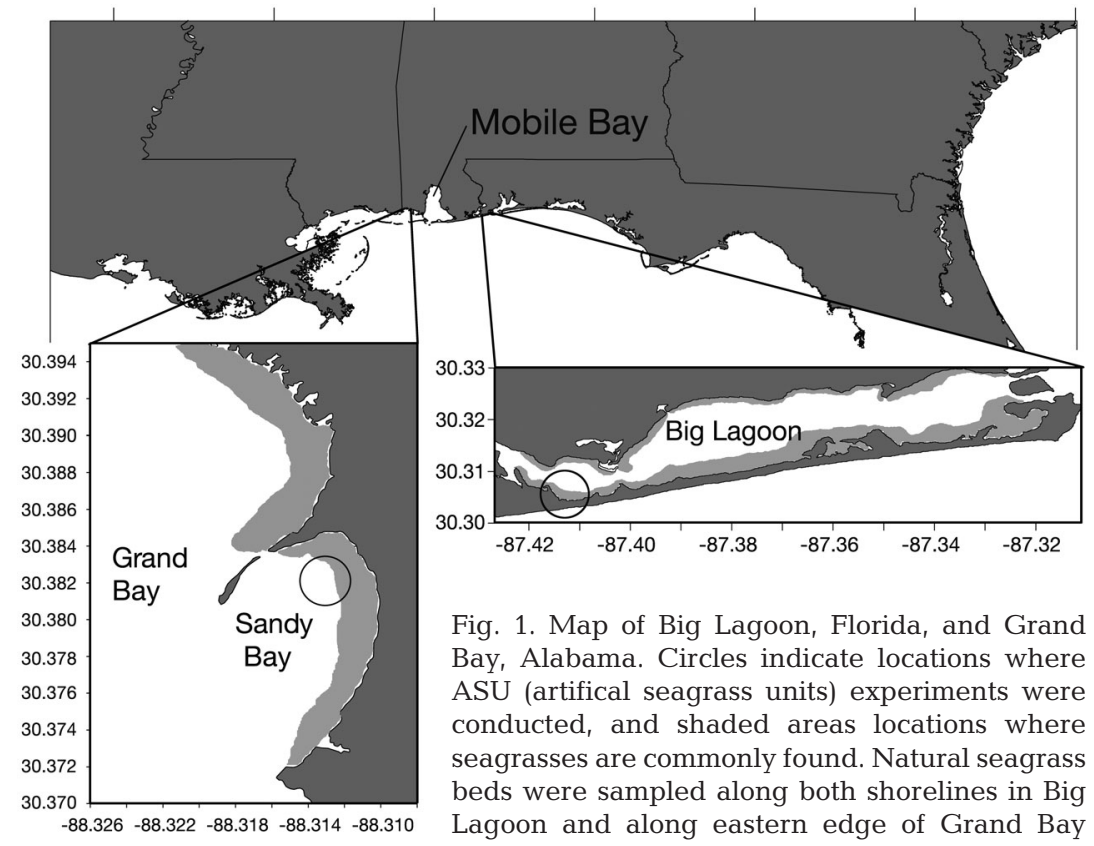

(Turner et al. 1999), and that which does exist has not produced consistent results. We do know that seagrass patch dynamics can influence many ecological processes; however, it is unknown if fragmentation negatively influences the productivity of seagrass-associated fauna. It is important to understand these processes to allow prediction of the effects of fragmentation before they occur and how they will affect the recovery process if habitats begin to coalesce.

The specific objective of this project was to use a combination of natural and artificial seagrass beds representing a wide range of seagrass patch configurations to determine if variation in seagrass bed size, shape, location within a bed and degree of isolation influences the abundance, composition and secondary production of decapod crustaceans and finfishes in turtlegrass Thalassia testudinum and shoalgrass Halodule wrightii meadows.

\section{MATERIALS AND METHODS}

Natural seagrass patches. In both Big Lagoon, Florida ( $\left.30^{\circ} 25^{\prime} \mathrm{N}, 87^{\circ} 18^{\prime} \mathrm{W}\right)$, and Grand Bay, Alabama $\left(30^{\circ} 23^{\prime} \mathrm{N}, 88^{\circ} 19^{\prime} \mathrm{W}\right)$ (Fig. 1), we chose between 7 and 10 seagrass patches that were similar in depth and plant density to represent a gradient in patch size, shape and isolation. In Big Lagoon, these patches were monospecific stands of Thalassia testudinum located along the northern and southern shorelines of the lagoon that varied in size from $<1$ to $2265 \mathrm{~m}^{2}$. In Grand Bay, we chose monospecific stands of Halodule wrightii along the eastern and northern shoreline of the bay that varied from $<1$ to $190 \mathrm{~m}^{2}$. Because truly monospecific stands of seagrasses are rare in the northern Gulf of Mexico, we operationally defined a monospecific bed as any seagrass bed that consisted of at least $85 \%$ of a single species of seagrass. In Big Lagoon, T. testudinum beds were often mixed with the faster growing species, $H$. wrightii. In Grand Bay, H. wrightii is the dominant seagrass; however, during the spring and early summer small stands of widgeongrass Ruppia maritima were present. These stands of $R$. maritima often die back as salinity increases throughout the summer (Stutes 2000).

We estimated the dimensions and perimeter of each seagrass patch using a 'Roll-a-tape ${ }^{\mathrm{TM}}$ ' measuring wheel. Because patches are often approximately elliptical, we measured the major and 
minor axes of each patch for use in area determinations. When beds were not elliptical, each bed was broken into several representative geometrical shapes and measurements were obtained to determine the area of each shape. The perimeter of each patch was determined by following the sand-seagrass interface using the measuring wheel. Inter-patch distance, or distance to the nearest seagrass patch (referred to as 'nearest neighbor'), was also measured using the measuring wheel. Patches were sampled at each location in June, August and October 2001. Because of inclement weather and poor visibility, it was necessary to sample Grand Bay during both August and September 2001 to obtain at least 7 patches. These samples were combined and treated as a single sample period labeled August 2001.

Organisms were sampled using a suction sampling technique that has been slightly modified from that of Orth \& von Montfrans (1987). Briefly, this sampling method employed a $1.6 \mathrm{~m}$ tall PVC cylinder with an internal diameter of $50 \mathrm{~cm}$ that was haphazardly placed in either the edge or the interior of the seagrass habitat and pushed firmly into the substrate. We defined the 'edge' as the vegetated area within $1 \mathrm{~m}$ of the sand-seagrass interface and 'interior' as more $>1 \mathrm{~m}$ from any sand-seagrass interface. Although this distance may not be appropriate for all species, it was identified as relevant in seagrass systems during several previous studies by Bell et al. (2001) and Hovel et al. (2002). The contents of the cylinder were evacuated for $30 \mathrm{~s}$ with a gasoline-powered suction dredge (see illustration in Orth \& van Montfrans 1987) and passed through a $0.5 \mathrm{~mm}$ mesh collection bag. The contents of the bag were stored on ice, transported back to the Dauphin Island Sea Laboratory, and frozen for further analysis. At the time of suction sampling, above ground seagrass biomass samples were collected by harvesting all shoots from two $0.01 \mathrm{~m}^{2}$ quadrats in each patch within the vicinity of the suction dredge sample. We also measured water temperature and salinity during each sampling effort for use in general habitat descriptions and for potential help in understanding unusual events.

Suction samples were thawed and sorted into the following major taxonomic groups: juvenile blue crabs Callinectes sapidus, shrimps (Palemonidae, Hippolytidae, Penaeidae), fishes (Gobiidae, Symphurus spp., Ophichthidae, Syngnathidae) and mud crabs (Xanthidae) (Big Lagoon only). Because of the likelihood of large-scale movements among patches, adult blue crabs ( $\geq 80 \mathrm{~mm}$ carapace width) and large penaeids ( $\geq 40 \mathrm{~mm}$ total length, TL) were not included in this analysis.

Above ground seagrass and epiphyte biomasses were determined by gently removing all epiphytes from a haphazardly collected subset ( $\geq 5$ turtlegrass leaves or $\geq 10$ shoalgrass leaves) of the seagrass leaves using a razor blade. The clean seagrass leaves and the removed epiphytes were collected and placed into 2 separate pans. All remaining unscraped seagrass leaves were carefully rinsed and placed into a third weighing pan. These pans were placed into a drying oven $\left(80^{\circ} \mathrm{C}\right)$ for at least $24 \mathrm{~h}$ and then weighed to the nearest $0.0001 \mathrm{~g}$. The samples were subsequently placed into a muffle furnace $\left(500^{\circ} \mathrm{C}\right)$ for $5 \mathrm{~h}$ and reweighed in order to calculate the ash free dry weight (AFDW). Total above ground biomass (AFDW) and epiphyte loads (AFDW) were calculated by determining the percentage of epiphytes present in the subsample and applying this value to the remaining unscraped leaves.

Secondary production estimates were calculated for total decapods (crabs plus caridean shrimps), caridean shrimps, and crabs (juvenile blue plus mud). In addition, separate estimates were calculated for juvenile blue crabs and mud crabs in Big Lagoon. Secondary production estimates were obtained by first determining the dry biomass (DW) of each sample to the nearest $0.0001 \mathrm{~g}$. This was done by drying each sample at $80^{\circ} \mathrm{C}$ to a constant weight. After the dry weight was measured, we determined the ash weight (AW) of the crabs and fishes by ashing them at $500^{\circ} \mathrm{C}$ for $5 \mathrm{~h}$. After ashing, the samples were placed in desiccators and allowed to cool prior to reweighing. AFDW was calculated as DW minus AW. Because of the low inorganic content of shrimp, AFDW was calculated as DW $\times 0.9$ (Waters 1977). We estimated secondary production using the equation provided by Robertson (1979): log $\mathrm{P} / \mathrm{B}=0.66-0.726 \log \mathrm{L}$, where $\mathrm{P}=$ annual production $(\mathrm{g}$ AFDW $\mathrm{m}^{-2} \mathrm{yr}^{-1}$ ), $\mathrm{B}=$ mean annual biomass ( $\mathrm{g}$ AFDW $\mathrm{m}^{-2}$ ) and $\mathrm{L}=$ lifespan in years. Because reliable estimates of lifespans are required for the application of this equation, and these are difficult to ascertain with confidence for invertebrates, we used both the longest and shortest lifespans published to provide a range of secondary production estimates. This method has been previously used by Valentine \& Heck (1993) and by Heck et al. (1995) to estimate ranges of secondary production in SAV habitats in Florida and in New England.

Data resulting from each of the 3 collection dates were analyzed using a stepwise multiple linear regression procedure (SPSS 2000). For abundances, separate analyses were calculated for total decapods, shrimps, fishes, juvenile blue crabs and mud crabs. For secondary production estimates, analyses were calculated for total decapods, caridean shrimps, crabs, juvenile blue crabs and mud crabs. Independent variables for all analyses were P:A ratio, nearest neighbor distance, above ground seagrass biomass, and epiphyte biomass. In addition, we conducted an additional linear 
regression analysis where area was the only independent variable. Densities were transformed using a $\log _{10}(x+1)$ transformation to satisfy the normality and homogeneity of variance assumptions of the linear regression model; however, in the few instances where the assumptions were not met, we feel that the robustness of this procedure ensures that results are reliable.

Differences between edges and interiors of seagrass patches were examined using 2-tailed $t$-tests for each dependent variable. When needed to meet the assumptions of the test, the data were transformed using a $\log _{10}(x+1)$ transformation. Environmental parameters for each sampling location were monitored to ensure similarities among patches.

Artificial seagrass units. Because of the possibility of covariance between structural complexity and area at the smallest naturally occurring patch sizes, 10 replicate ASUs were deployed in June, August and October 2001 at each of the study locations. We must note that the June sampling occurred on July 2 (Big Lagoon) and 9 and is referenced as such in the figures and tables. These ASUs varied in both size (large and small) and shape (stellate and circular), thus also varying in area and P:A ratios (Bologna \& Heck 1999, 2000). In Table 1, the differences in area and P:A are shown for 2 different-sized ASUs of each shape. We used $1.9 \mathrm{~cm}$ black Vexar mesh as a substrate to which artificial seagrass leaves were attached; $5 \mathrm{~mm}$ wide, smooth finish, green polypropylene ribbon was used to simulate Thalassia testudinum leaves, and $2.5 \mathrm{~mm}$ wide ribbon was used to simulate Halodule wrightii leaves. Shoot density was 2400 leaves $\mathrm{m}^{-2}$ for $T$. testudinum and 10000 leaves $\mathrm{m}^{-2}$ for $H$. wrightii, mid ranges of field-measured values during 1997 and 1998 at the field sites (Stutes 2000, K. L. Heck \& J. F. Valentine unpubl.). ASUs were placed on barren sand (Big Lagoon) and sand/mud (Grand Bay) flats, $5 \mathrm{~m}$ apart and at least $5 \mathrm{~m}$ from any living seagrass, and allowed to undergo colonization for $4 \mathrm{wk}$, after which time they were sampled with the suctiondredging technique described in the foregoing subsection. Because of the relatively small size of the ASUs, only a single suction sample was collected from each, using a shape-specific suction appliance that encompassed the entire ASU (no discrimination between edge

Table 1. Dimensions of ASUs deployed in Big Lagoon, Florida, and Grand Bay, Alabama, in 2001. ASUs differed in size (large/small) and shape (stellate/circular)

\begin{tabular}{|lcccc|}
\hline & \multicolumn{2}{c}{ Large } & \multicolumn{2}{c|}{ Small } \\
& Stellate & Circular & Stellate & Circular \\
\hline Area $\left(\mathrm{m}^{2}\right), \mathrm{A}$ & 0.2036 & 0.2036 & 0.0487 & 0.0487 \\
Perimeter $(\mathrm{m}), \mathrm{P}$ & 3.265 & 1.6 & 1.6 & 0.7825 \\
P:A ratio & 16.04 & 7.86 & 32.85 & 16.07 \\
& & & & \\
\hline
\end{tabular}

and interior), the ASU was sampled for a minimum of 1 min. To ensure that all macrofaunal organisms had been removed, a small dip net was passed through any seawater remaining within the suction appliance.

Sample processing and secondary production estimates were done in a manner similar to that for natural seagrass beds; however, grouping for density and secondary production estimates varied slightly. Groupings for density values were: total decapods; total fishes; total crabs; juvenile blue crabs; mud crabs; juvenile penaeids $(\leq 40 \mathrm{~mm})$; caridean shrimps. Groupings for production values were: total decapods (total crabs plus total shrimps); total crabs (juvenile blue plus mud); total shrimps (small penaeid plus caridean); total fishes (Gobiidae, Symphurus spp., Ophichthidae, Syngnathidae). In addition, because of the large amount of time required to process samples from Big Lagoon in June 2001, a haphazardly chosen subset of ASUs (Table 2) from each remaining sample date was randomly selected and processed in lieu of processing all 10 replicates.

The lifespan estimate for secondary production of the fish group was derived for the numerically dominant fish (Gobiosoma robustum: $84.4 \%$ of total). Since no reliable estimates exist for this species, lifespan estimates were obtained for $G$. bosci, a species with identical life history that is often confused with G. robustum. Because G. bosci is considered to be an annual species (Peterson et al. 2003), we used 1.5 and $0.5 \mathrm{yr}$ as our high and low lifespan estimates, respectively.

Abundance and secondary production data from the ASU experiments were analyzed using a 2-way ANOVA with patch size (large and small) and patch shape (stellate and circular) as factors. In addition, we examined each sample date separately. Post-hoc analyses were carried out using Fisher's least significant difference (LSD) test. All densities were transformed using a $\log _{10}(x+1)$ transformation to meet the normality and homogeneity of variance assumptions of the ANOVA model; however, in the few instances where the assumptions were not met, the robustness of this procedure ensures that the results are reliable. In addition, we used linear regression techniques (SPSS stepwise process) to examine the relationship between perimeter:area ratios and organism abundance and production.

Table 2. Sample sizes for ASU experiment for Big Lagoon and Grand Bay during 2001. L: large; S: small patches

\begin{tabular}{|c|c|c|c|c|c|}
\hline \multicolumn{3}{|c|}{-Big Lagoon } & \multicolumn{3}{|c|}{-Grand Bay } \\
\hline Date & Stellate & Circular & Date & Stellate & Circular \\
\hline Jul 2 & $10 \mathrm{~L}, 10 \mathrm{~S}$ & $10 \mathrm{~L}, 10 \mathrm{~S}$ & Jul 9 & $5 \mathrm{~L}, 5 \mathrm{~S}$ & $5 \mathrm{~L}, 5 \mathrm{~S}$ \\
\hline Aug 29 & $5 \mathrm{~L}, 8 \mathrm{~S}$ & $6 \mathrm{~S}, 6 \mathrm{~S}$ & Aug 30 & $5 \mathrm{~L}, 5 \mathrm{~S}$ & $5 \mathrm{~L}, 5 \mathrm{~S}$ \\
\hline Oct 24 & $5 \mathrm{~L}, 5 \mathrm{~S}$ & $5 \mathrm{~S}, 6 \mathrm{~S}$ & Aug 30 & $5 \mathrm{~L}, 4 \mathrm{~S}$ & $5 \mathrm{~L}, 5 \mathrm{~S}$ \\
\hline
\end{tabular}




\section{RESULTS}

\section{Physical environment}

Water temperatures at Big Lagoon during the experiment ranged between 19 and $32.5^{\circ} \mathrm{C}$ (NOAA data: available at http://co-ops.nos.noaa.gov/data_retrieve. shtml). October was the coolest month with temperatures averaging $20.8^{\circ} \mathrm{C}$, while June and August had mean temperatures of 29.6 and $30.0^{\circ} \mathrm{C}$, respectively. Salinity during the experiment ranged between 23 and 35. Salinity in June and August ranged between 23 and 29, while salinity in October averaged 34.8.

Water temperatures at Grand Bay ranged between 20 and $31^{\circ} \mathrm{C}$ during the summer/fall of 2001. As expected, mean temperatures decreased between July and October and remained seasonable for that time period (NOAA data). Salinity during the experiment ranged between 10 and 31. During June 2001, mean salinity was 12, while in August and October mean salinities were 23 and 28, respectively.

\section{Natural seagrass patches}

\section{Big Lagoon}

Distributional patterns indicated minimal monthly variation, with all taxa occurring during each sample period. In addition, all species were collected over the entire range of sizes of seagrass beds sampled (Fig. 2). Blue crabs and mud crabs were collected in 42 and $70 \%$ of the suction samples, respectively; while caridean and penaeid shrimps were present in 94 and $39 \%$ of the samples collected, respectively. Penaeid shrimps did exhibit a seasonal density increase of approximately $25 \%$ between the sample periods. Gobies (primarily Gobiosoma robustum) were the numerically dominant species collected, comprising $71 \%$ of the total fish abundance, and were present in $39 \%$ of the samples. The remaining $29 \%$ of the fishes collected consisted of blackcheek tonguefish Symphurus plagiusa (13\%), speckled worm eels Myrophis punctatus (7\%) and pipefishes Syngnathus spp. (9\%). Total fish densities ranged between 0 and 82 fishes $\mathrm{m}^{-2}$ (Fig. 2).

Low lifespan estimates of productivity of all decapods combined ranged between 0.04 and $14.7 \mathrm{~g}$ AFDW m ${ }^{-2} \mathrm{yr}^{-1}$ for natural seagrass beds in Big Lagoon. High lifespan estimates ranged between 0.02 and $6.8 \mathrm{~g} \mathrm{AFDW} \mathrm{m}^{-2} \mathrm{yr}^{-1}$. Caridean shrimps represented the largest amount of decapod production in Big Lagoon; in $81 \%$ of the samples collected, they accounted for more than half the biomass production. Maximum estimated caridean shrimp production was $8.2 \mathrm{~g} \mathrm{AFDW} \mathrm{m}^{-2} \mathrm{yr}^{-1}$ (low lifespan estimate), minimum estimated production $0.03 \mathrm{~g} \mathrm{AFDW} \mathrm{m}^{-2} \mathrm{yr}^{-1}$ (high lifespan estimate). When mud crabs were present, they comprised the next most productive group, with low lifespan estimates ranging between 0.006 and $13.4 \mathrm{~g}$ AFDW $\mathrm{m}^{-2} \mathrm{yr}^{-1}$ and high lifespan estimates ranging between 0.003 and $6.01 \mathrm{~g} \mathrm{AFDW} \mathrm{m}^{-2} \mathrm{yr}^{-1}$. Blue crabs were the least common decapod and represented the smallest amount of annual production in Big Lagoon. Estimated annual productivities of blue crabs ranged between 0.02 and 3.5 for low lifespans, and between 0.002 and $6.1 \mathrm{~g}$ AFDW $\mathrm{m}^{-2} \mathrm{yr}^{-1}$ for high lifespan estimates.

Stepwise multiple linear regression analysis revealed little of the relationships between organism densities and perimeter:area ratio, distance to nearest neighbor, above ground seagrass biomass and epi-
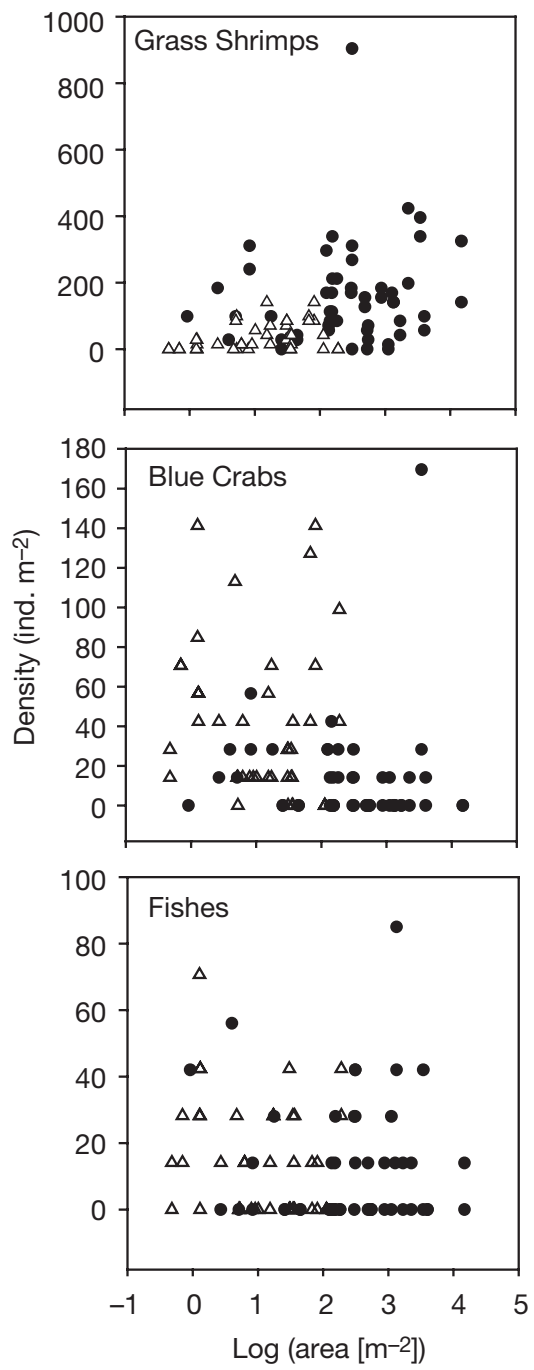

Fig. 2. Densities of grass shrimps, blue crabs, and total fishes within different-sized patches in (•) Thalassia testudinum beds in Big Lagoon and $(\Delta)$ Halodule wrightii beds in Grand Bay between June and October 2001 
phyte biomass. No multiple regression models were significant for data collected in Big Lagoon, nor were there any significant relationships between secondary production estimates and any independent variables. The only significant regressions resulting from this procedure were simple linear regressions between fish density and distance to nearest neighbor, and between mud crab densities and perimeter:area ratios (Fig. 3). Our regression analysis between patch area and both abundance and production resulted in a single significant relationship with mud crab density $\left(F_{1,50}=12.16\right.$, $p=0.001$ ). The resulting relationship was positive and could be described by the relationship $\log _{10}$ (ind. $\mathrm{m}^{-2}$ ) $=0.19+0.35 \times \log _{10}$ (area), $\mathrm{r}^{2}=0.20$.

Mud crabs were the only organisms showing significant differences between the edge and interior of patches. The mean $( \pm \mathrm{SE})$ number of mud crabs found
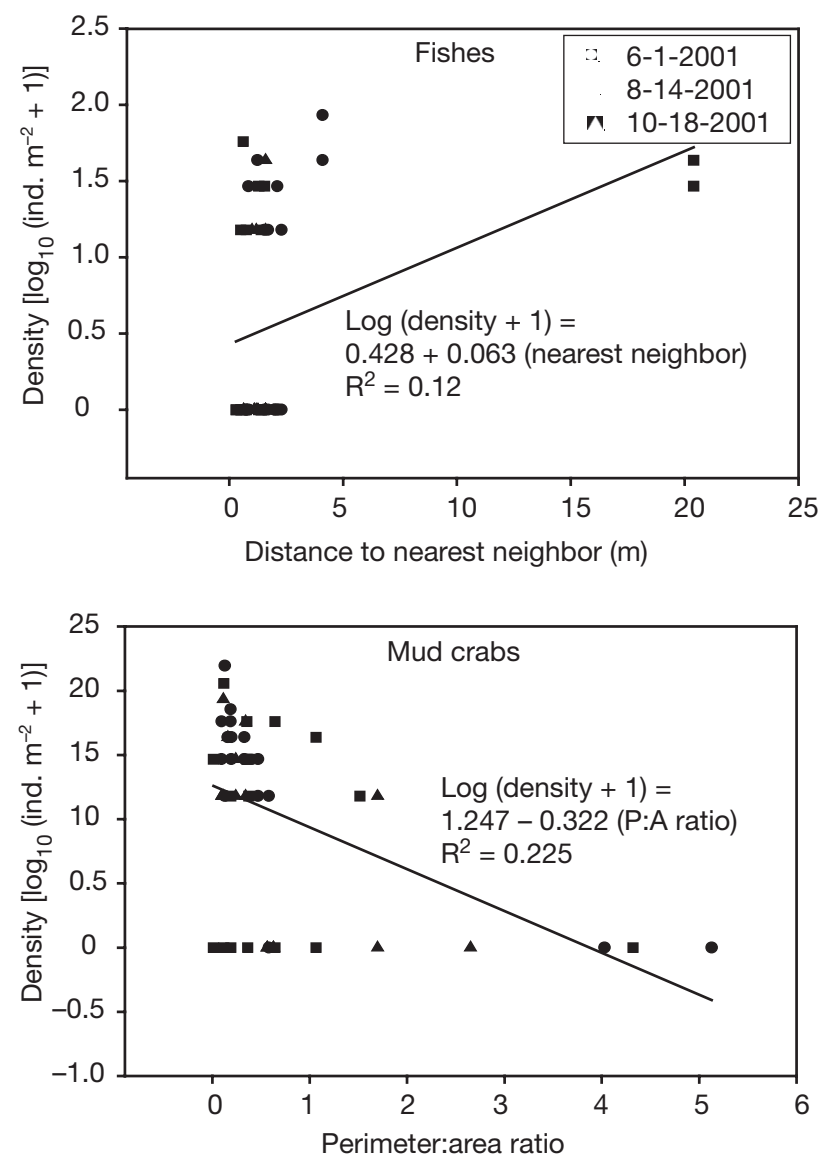

Fig. 3. Significant stepwise multiple linear regressions for Big Lagoon (Thalassia testudinum) meadows computed using organism density as dependent variable, and perimeter:area ratio, distance to nearest neighbor, above-ground seagrass biomass and epiphtyic biomass as independent variables. Distance to nearest neighbor measured as shortest distance between 2 adjacent seagrass beds. Here and in subsequent figures, dates presented as mm-dd-yyyy in the interior was $39.14 \pm 7.6 \mathrm{crabs} \mathrm{m}^{-2}$, which was significantly greater (Student's $t=2.711, \mathrm{df}=50, \mathrm{p}=$ 0.009 ) than crab density in the edge (mean $=15.6 \pm$ $3.5 \mathrm{crabs} \mathrm{m}^{-2}$ ). Production estimates for both the high and low lifespan estimates of mud crabs were significantly higher (high: $t=2.062, \mathrm{df}=50, \mathrm{p}=0.044$; low: $t=2.091, \mathrm{df}=50, \mathrm{p}=0.42$ ) for the interior of the patches. High lifespan estimates of mean production were $0.59 \pm 0.26 \mathrm{~g} \mathrm{AFDW} \mathrm{m}^{-2} \mathrm{yr}^{-1}$ and $0.09 \pm 0.04 \mathrm{~g}$ AFDW $\mathrm{m}^{-2} \mathrm{yr}^{-1}$ for patch interiors and exteriors, respectively. The low lifespan estimates of mean production for the patch were $1.3 \pm 0.57 \mathrm{~g} \mathrm{AFDW} \mathrm{m}^{-2}$ $\mathrm{yr}^{-1}$ (interior) and $0.204 \pm 0.08 \mathrm{~g}$ AFDW m $\mathrm{m}^{-2} \mathrm{yr}^{-1}$ (exterior).

\section{Grand Bay}

Caridean and penaeid shrimps, juvenile blue crabs and fishes were present at each sample period and collected over the entire range of patch sizes (Fig. 2); however, densities showed little variation in the summer/fall of 2001. Blue crabs and caridean shrimps were present in 61 and $86 \%$ of the samples, respectively, and were the most abundant organisms collected. Penaeid shrimps and fishes were present in 45 and $54 \%$ of the samples collected, respectively. Gobies (primarily Gobiosoma robustum) comprised $45 \%$ of the total fishes collected, occurring in densities ranging between 0 and $42 \mathrm{~m}^{-2}$. Blackcheek tonguefish Symphurus plagiusa (38\%), speckled worm eels Myrophis punctatus $(9 \%)$ and pipefish Syngnathus spp. (7\%) were present at densities ranging between 0 and 28 ind. $\mathrm{m}^{-2}$.

High lifespan estimates of annual productivity of all decapods combined ranged between 0.003 and $38.2 \mathrm{~g}$ AFDW $\mathrm{m}^{-2} \mathrm{yr}^{-1}$. Low lifespan estimates ranged between 0.006 and $83.5 \mathrm{~g} \mathrm{AFDW} \mathrm{m}^{-2} \mathrm{yr}^{-1}$. Caridean shrimps represented at least $75 \%$ of the total production in $43 \%$ of the samples, while crab production was at least $75 \%$ of the total production in $40 \%$ of samples. There was an overall increase in crab production and a decrease in shrimp production between June and October. The maximum estimated caridean shrimp production was $20.7 \mathrm{~g}$ AFDW $\mathrm{m}^{-2} \mathrm{yr}^{-1}$ (low lifespan estimate), while the minimum estimated production when shrimp were present was $0.14 \mathrm{~g} \mathrm{AFDW} \mathrm{m}^{-2} \mathrm{yr}^{-1}$ (high lifespan estimate). When crabs were present, they had high lifespan production estimates ranging between 0.0002 and $36.0 \mathrm{~g} \mathrm{AFDW} \mathrm{m}^{-2} \mathrm{yr}^{-1}$ and low lifespan estimates ranging between 0.0005 and $79.9 \mathrm{~g}$ AFDW m ${ }^{-2} \mathrm{yr}^{-1}$.

Stepwise multiple linear regression analyses indicated that the only significant relationships between abundance and any independent variable were 


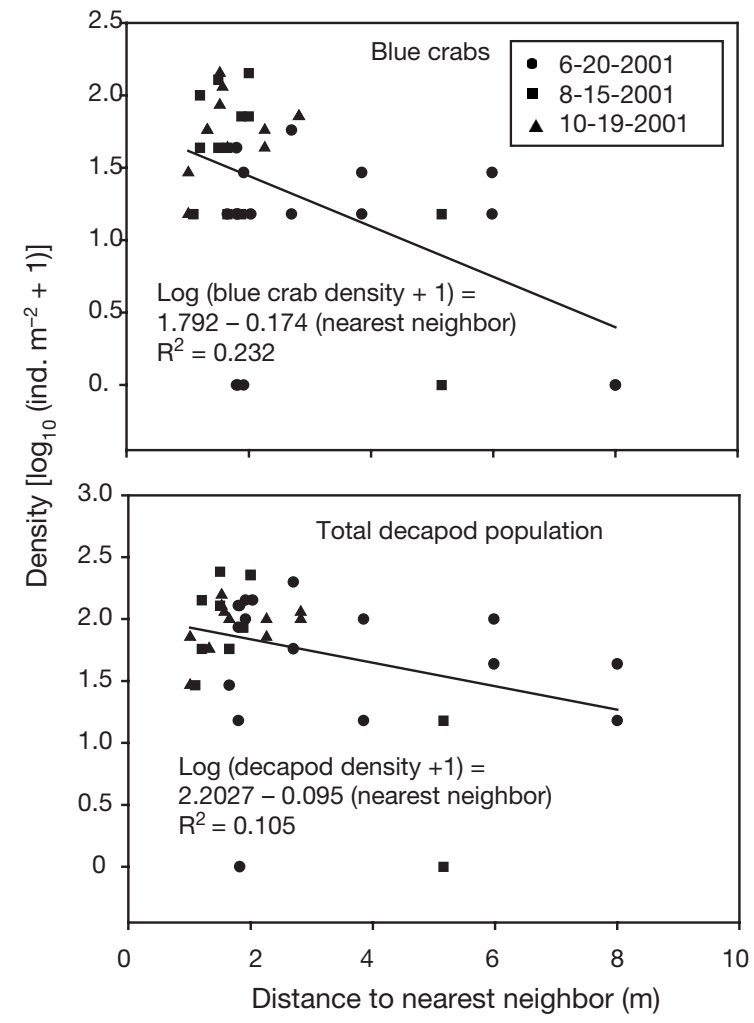

Fig. 4. Significant stepwise multiple linear regressions for Grand Bay. Details as in Fig. 3 legend

between both blue crab and total decapod densities and the distance a patch was located from its closest neighbor (Fig. 4). Secondary production estimates did not show significant relationships with any of the independent variables. Student's $t$-tests comparing abundances and secondary production within patch interiors versus exteriors found no significant differences for any of the dependent variables.

\section{Artificial seagrass units}

Big Lagoon

During the June ASU sampling effort, fishes, primarily Gobiosoma robustum, were most abundant, followed by blue crabs, carideans, penaeids and mud crabs (Fig. 5). There were no significant density differences among the four different ASUs for any of the organisms captured (Fig. 5). In August, blue crabs, caridean shrimps, and fishes remained the most common groups. No mud crabs and only a single penaeid shrimp were collected during this period. Caridean shrimp abundance varied significantly with patch size, but not with patch shape (size: $F_{1,1}=6.773, \mathrm{p}=0.016$; shape: $\left.F_{1,1}=2.540, \mathrm{p}=0.125\right)$ mean abundance $( \pm \mathrm{SE})$ on the large and small ASUs was $68.8 \pm 35$ and $29.1 \pm$ $12.6 \mathrm{~m}^{-2}$, respectively (Fig. 5). During October, caridean shrimp abundance surpassed that of fishes, and they became the most abundant group (Fig. 5). Blue crabs and fishes were also common during this period, and were present at densities similar to those in other collection periods. Penaeid shrimp densities increased by $387 \%$ during this period, while mud crabs were uncommon ( 1.4 mud crabs $\left.\mathrm{m}^{-2}\right)$ and were only present on large ASUs. As a result, mud crabs were significantly more abundant on large ASUs (size: $F_{1,1}=6.836, \mathrm{p}=0.018$; shape: $\left.F_{1,1}=2.153, \mathrm{p}=0.161\right)$. In addition, significantly more caridean shrimps (size: $F_{1,1}=11.244, \mathrm{p}=0.004 ;$ shape: $F_{1,1}=1.632, \mathrm{p}=0.423$ ) and decapods (size: $F_{1,1}=13.044, \mathrm{p}=0.002$; shape: $F_{1,1}=0.147, \mathrm{p}=0.300$ ) were collected in the large than the small ASUs (Fig. 5).

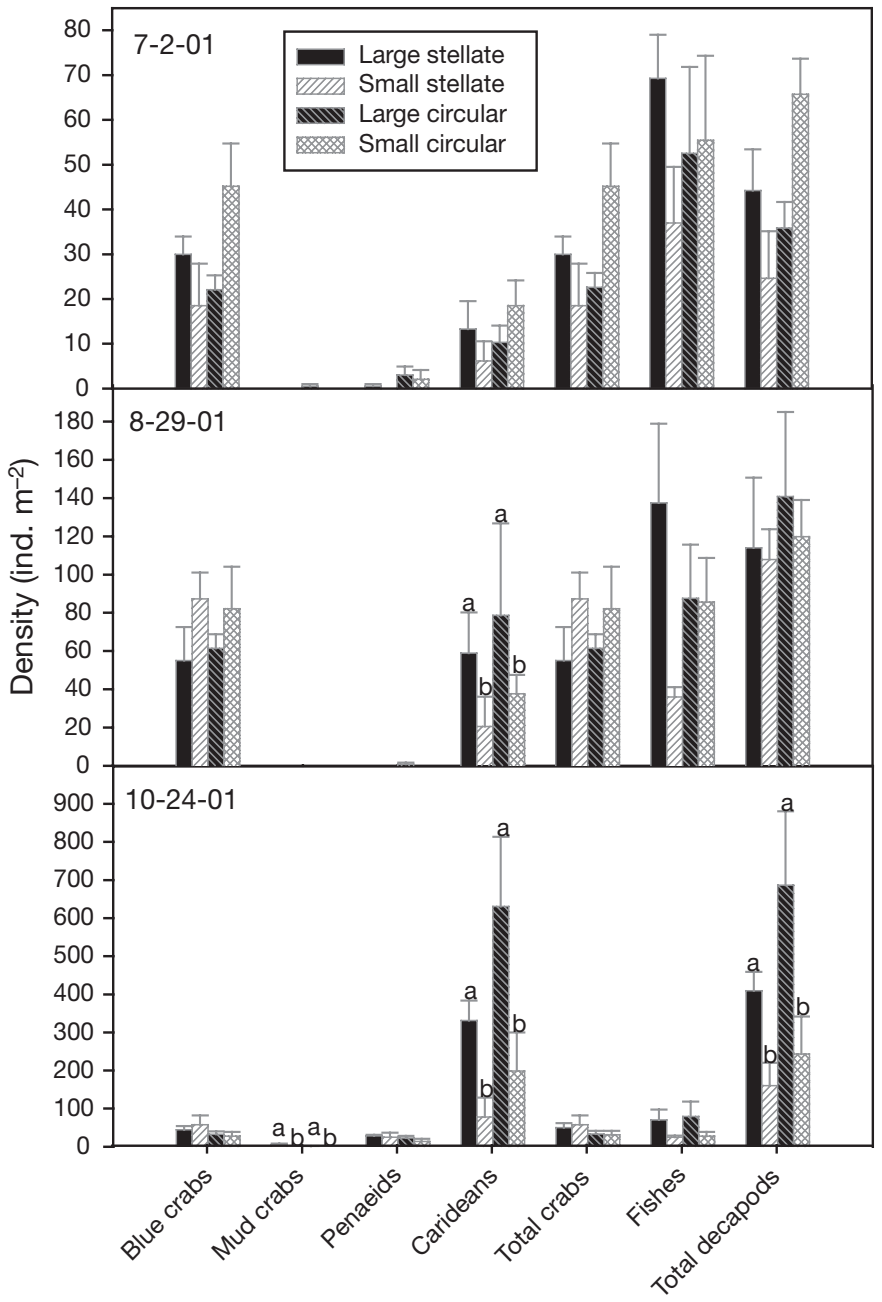

Fig. 5. Mean (+SE) densities of animals collected from artificial seagrass units (ASUs) in Big Lagoon. Significant $(p<0.05)$ differences and post-hoc groupings indicated by lowercase letters 
High and low lifespan estimates of production were significantly greater in the large than the small ASUs for crabs (high and low size: $F_{1,1}=7.842, \mathrm{p}=0.01$; shape: $F_{1,1}=1.401, \mathrm{p}=0.245$ ) and fishes (high and low size: $F_{1,1}=7.283, \mathrm{p}=0.014$; shape: $F_{1,1}=2.233, \mathrm{p}=$ 0.15) (Table 3). For decapods, there were general increases in secondary production between June and October within each type of ASU, but changes were similar among the 4 ASU types. For fishes, production peaked in August and there were no similarities in trends temporally or among ASU types.

Table 3. Secondary production estimates $\left(\mathrm{g}\right.$ AFDW $\mathrm{m}^{-2}$ ) of crab and shrimp populations that colonized Thalassia testudinum artificial seagrass units in Big Lagoon, Florida, in 2001, with high and low estimates of lifespan. Superscripts indicate significant differences $(2$-way ANOVA, $\mathrm{p}<0.05)$ and appropriate groupings. Crab lifespan estimates from Warner (1977), shrimp lifespan estimates from Bauer (1989), fish lifespan estimates from Peterson et al. (2003)

\begin{tabular}{|c|c|c|c|c|}
\hline \multirow{2}{*}{$\begin{array}{l}\text { Organism, } \\
\quad \text { lifespan (yr) }\end{array}$} & \multicolumn{2}{|c|}{ Stellate } & \multicolumn{2}{|c|}{ Circular } \\
\hline & Large & Small & Large & Small \\
\hline \multicolumn{5}{|l|}{ Jul 9} \\
\hline \multicolumn{5}{|l|}{ Crabs } \\
\hline 3 & $0.15^{\mathrm{a}}$ & $0.03^{\mathrm{b}}$ & $0.13^{\mathrm{a}}$ & $0.11^{\mathrm{b}}$ \\
\hline 1 & $0.34^{\mathrm{a}}$ & $0.06^{b}$ & $0.29^{\mathrm{a}}$ & $0.25^{\mathrm{b}}$ \\
\hline \multicolumn{5}{|l|}{ Shrimps } \\
\hline 0.42 & 0.11 & 0.03 & 0.16 & 0.63 \\
\hline 0.17 & 0.22 & 0.06 & 0.32 & 1.25 \\
\hline \multicolumn{5}{|l|}{ Decapods } \\
\hline High & 0.26 & 0.06 & 0.28 & 0.74 \\
\hline Low & 0.56 & 0.12 & 0.61 & 1.50 \\
\hline \multicolumn{5}{|l|}{ Fishes } \\
\hline 1.5 & 0.54 & 0.50 & 0.35 & 1.38 \\
\hline 0.5 & 1.24 & 1.15 & 0.81 & 3.17 \\
\hline \multicolumn{5}{|l|}{ Aug 29} \\
\hline \multicolumn{5}{|l|}{ Crabs } \\
\hline 3 & 0.36 & 0.61 & 0.34 & 0.61 \\
\hline 1 & 0.83 & 1.41 & 0.77 & 1.42 \\
\hline \multicolumn{5}{|l|}{ Shrimps } \\
\hline 0.42 & 3.72 & 0.01 & 1.12 & 0.71 \\
\hline 0.17 & 7.39 & 0.26 & 2.22 & 1.41 \\
\hline \multicolumn{5}{|l|}{ Decapods } \\
\hline High & 4.08 & 0.74 & 1.45 & 1.32 \\
\hline Low & 8.22 & 1.67 & 3.00 & 2.82 \\
\hline \multicolumn{5}{|l|}{ Fishes } \\
\hline 1.5 & $3.07^{\mathrm{a}}$ & $0.39^{\mathrm{b}}$ & $1.08^{\mathrm{a}}$ & $0.66^{\mathrm{b}}$ \\
\hline 0.5 & $7.07^{\mathrm{a}}$ & $0.89^{b}$ & $2.22^{\mathrm{a}}$ & $1.51^{\mathrm{b}}$ \\
\hline \multicolumn{5}{|l|}{ Oct 24} \\
\hline \multicolumn{5}{|l|}{ Crabs } \\
\hline 3 & 0.66 & 0.32 & 0.18 & 0.13 \\
\hline 1 & 1.52 & 0.73 & 0.42 & 0.29 \\
\hline \multicolumn{5}{|l|}{ Shrimps } \\
\hline 0.42 & 5.58 & 8.65 & 7.78 & 3.66 \\
\hline 0.17 & 11.09 & 17.20 & 15.47 & 7.28 \\
\hline \multicolumn{5}{|l|}{ Decapods } \\
\hline High & 6.24 & 8.97 & 7.96 & 3.79 \\
\hline Low & 12.61 & 17.93 & 15.88 & 7.57 \\
\hline \multicolumn{5}{|l|}{ Fishes } \\
\hline 1.5 & 0.18 & 0.66 & 0.42 & 0.12 \\
\hline 0.5 & 0.42 & 1.53 & 0.96 & 0.27 \\
\hline
\end{tabular}

Regression analysis of the relationship among perimeter:area ratios and organism density in the ASUs indicated that P:A ratios may exert some influence over decapod settlement and production. There was a negative relationship among P:A ratios and blue crab, caridean shrimp and total decapod densities, as well as crab production (Fig. 6). However, these results were not consistent among the 3 sample periods and only explained between 15 and $35 \%$ of the variance.

\section{Grand Bay}

Blue crabs, mud crabs, penaeid shrimps and caridean shrimps were all present during June 2001. Although not significantly different, caridean shrimp densities were greater on large ASUs, while blue crabs and mud crabs were collected in larger numbers on small ASUs (Fig. 7). Combined, total crab density was significantly different between the large and small ASUs (size: $F_{1,1}=7.040, \mathrm{p}=0.017$; shape: $F_{1,1}=0.192$, $\mathrm{p}=0.667)$. Fishes collected at this time consisted of $70 \%$ Gobiosoma robustum, 17\% blackcheek tonguefish, and $11 \%$ speckled worm eels and 2-way ANOVAs indicated no significant relationship between ASU size or shape and fish abundance. In August, there was an increase in the overall numbers of penaeid shrimps and blue crabs compared to June. Both organisms were more abundant on stellate than circular ASUs; however, penaeid shrimps comprised the only taxon that was significantly different (size: $F_{1,1}=1.265, \mathrm{p}=$ 0.277; shape: $F_{1,1}=4.737, \mathrm{p}=0.045$ ) (Fig. 7). October sampling resulted in few changes from the previous sampling date, but there was an overall increase in penaeid densities. No significant differences in abundances were detected during this period.

Secondary production estimates for crabs and decapods in June 2001 indicated that the largest amount of production in Grand Bay was due to penaeid and caridean shrimps (Table 4). For this date, large ASUs were responsible for significantly more (size: $F_{1,1}=5.102$, $\mathrm{p}=0.038$; shape: $\left.F_{1,1}=0.00, \mathrm{p}=0.999\right)$ production of decapods for the low lifespan estimate. Fish production, although not significantly different, was greater on small ASUs (Table 4). During August, shrimps were still responsible for more secondary production than crabs; however, there were no significant differences or general trends evident between patch size and patch shape for decapods. Fish secondary production, on the other hand, was significantly larger on stellate ASUs during June (high and low size: $F_{1,1}=0.01, p=0.92$; shape: $F_{1,1}=5.580, \mathrm{p}=0.031$ ). In October, patch size played a larger role in crab and overall decapod production than in the other sample periods. Large ASUs showed significantly more crab production (high and low size: $F_{1,1}=$ 
10.051, $\mathrm{p}=0.006$; shape: $F_{1,1}=0.028, \mathrm{p}=0.87$ ) and overall decapod production (high- size: $F_{1,1}=5.427, \mathrm{p}=$ 0.033 ; shape: $F_{1,1}=0.188, \mathrm{p}=0.671$ : low size: $F_{1,1}=$ $11.812, \mathrm{p}=0.003$; shape: $F_{1,1}=0.165, \mathrm{p}=0.69$ ) than the small ASUs (Table 4). In addition, shrimp secondary production was consistently higher in the large ASUs than the small ASUs. Fish secondary production was greatest on the large stellate ASUs, but there was no significant or consistent pattern.

Regression analysis between perimeter:area ratios and animal density or secondary production estimates resulted in few significant relationships among vari-

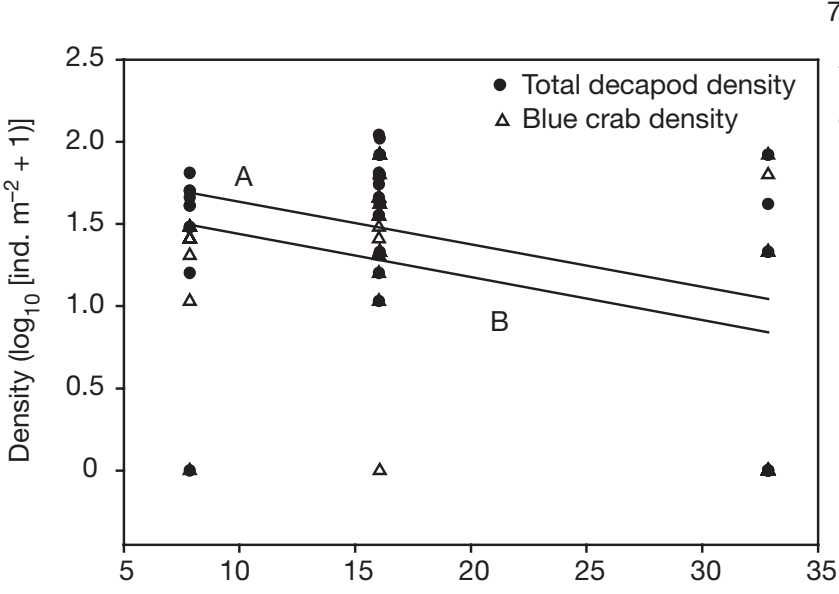

7-2-01
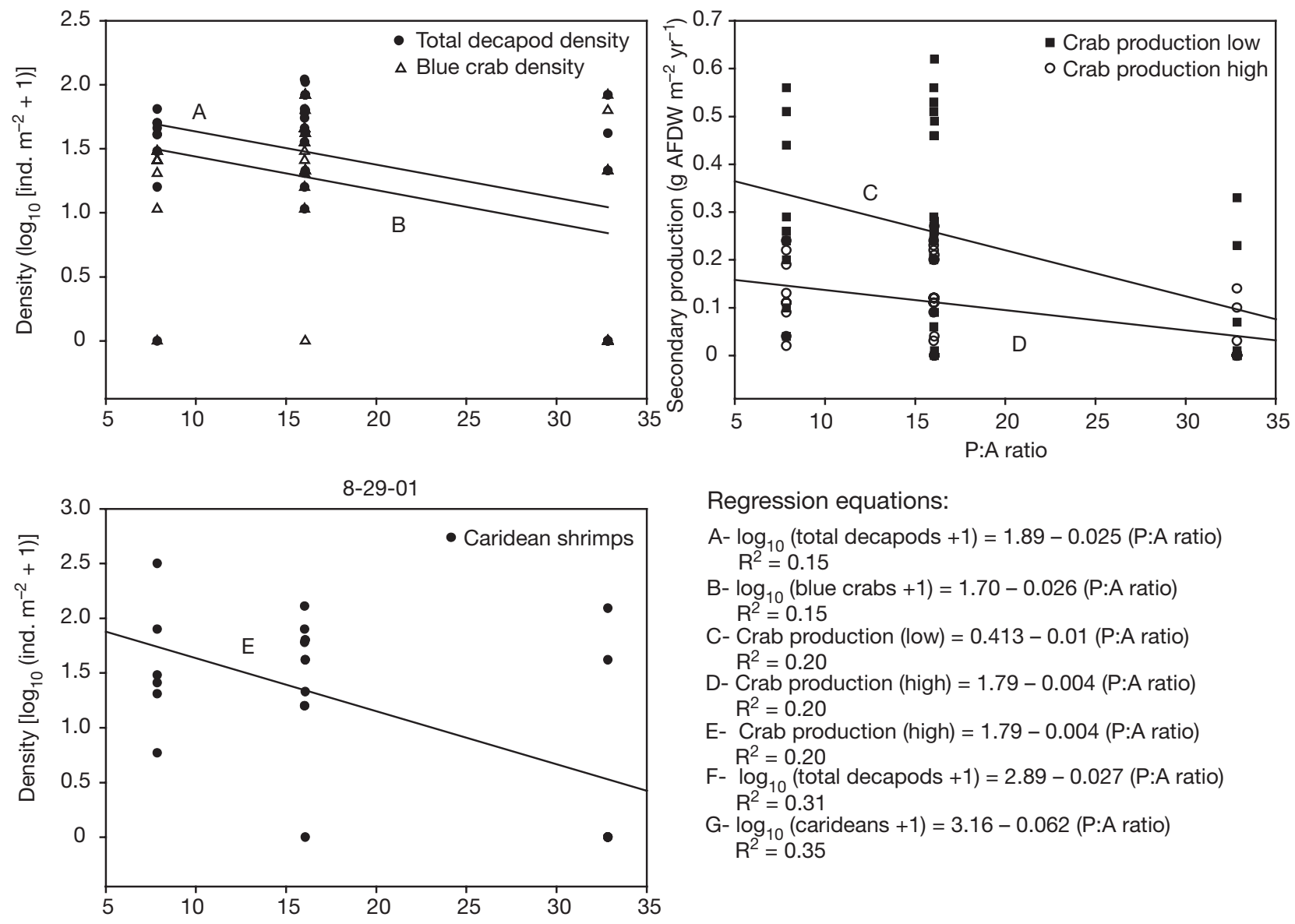

Regression equations:

A- $\log _{10}$ (total decapods +1$)=1.89-0.025$ (P:A ratio) $R^{2}=0.15$

B- $\log _{10}($ blue crabs +1$)=1.70-0.026(\mathrm{P}:$ A ratio $)$ $R^{2}=0.15$

C- Crab production (low) $=0.413-0.01$ (P:A ratio) $R^{2}=0.20$

D- Crab production (high) $=1.79-0.004(\mathrm{P}:$ A ratio) $R^{2}=0.20$

E- Crab production (high) $=1.79-0.004$ (P:A ratio) $R^{2}=0.20$

F- $\log _{10}$ (total decapods +1$)=2.89-0.027$ (P:A ratio) $R^{2}=0.31$

G- $\log _{10}$ (carideans +1$)=3.16-0.062$ (P:A ratio) $R^{2}=0.35$

10-24-01
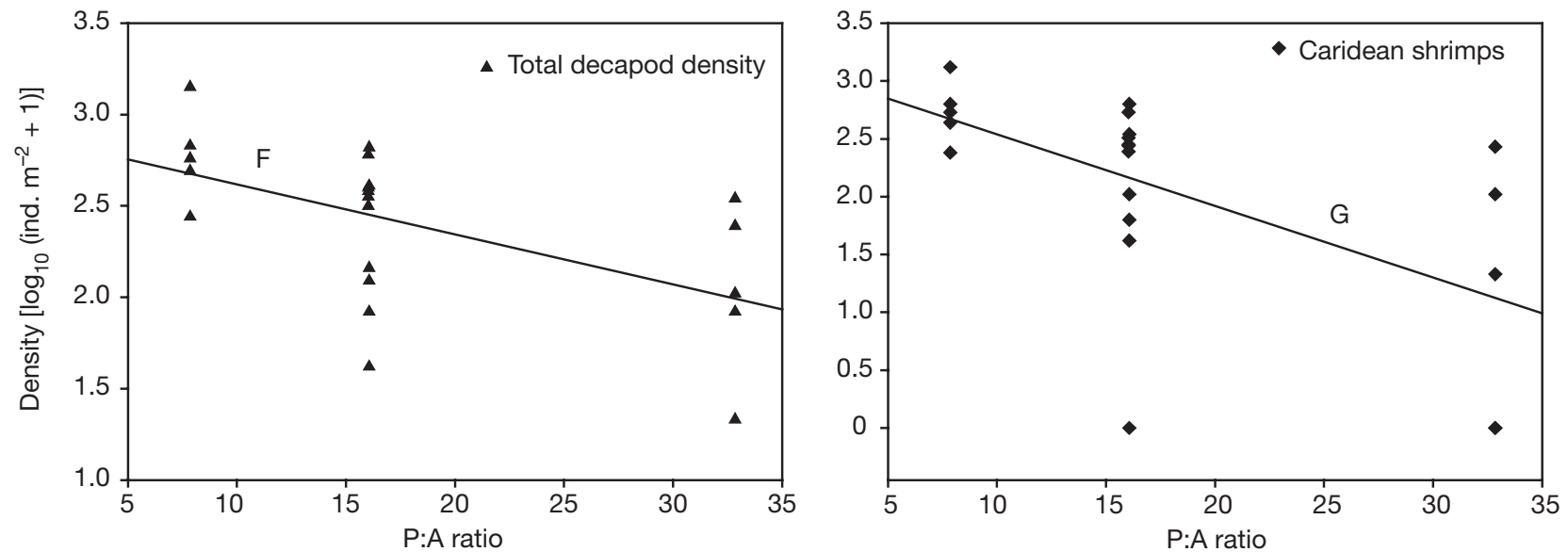

Fig. 6. Significant $(\mathrm{p}<0.05)$ linear regressions for density and secondary production estimates versus perimeter:area (P:A) ratio for ASUs in Big Lagoon. For August 2001, caridean shrimp were only collected from 2 of the 8 small stellate ASUs (P:A = 32.85) 


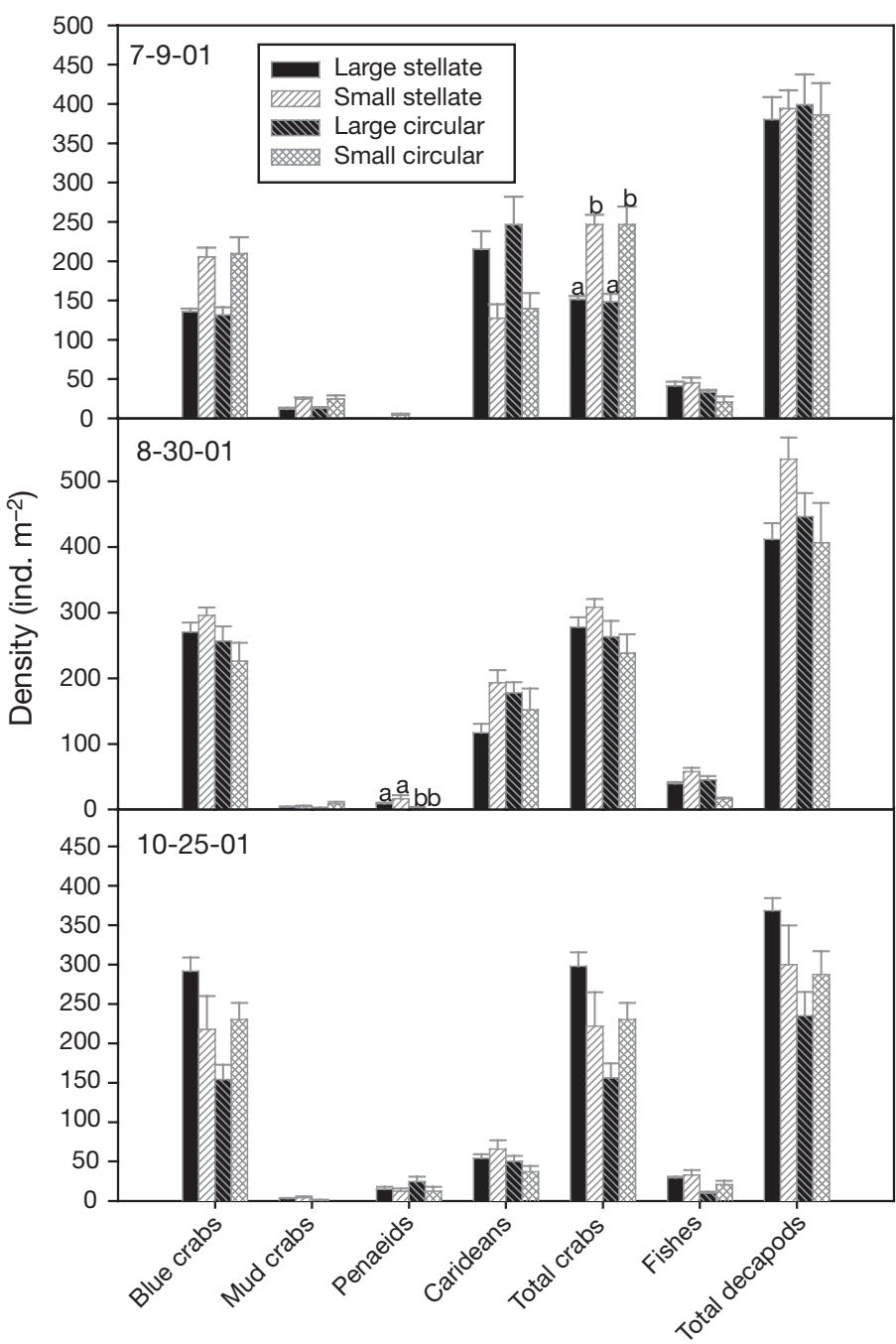

Fig. 7. Mean (+SE) densities of animals collected from artificial seagrass units in Grand Bay. Significant $(p<0.05)$ differences and post-hoc groupings indicated by lowercase letters

ables. During June, crab abundance had a significant positive relationship $\left(F_{1,18}=4.48, \mathrm{p}=0.045\right)$ with $\mathrm{P}: \mathrm{A}$ ratios (Fig. 8). In August, there were no significant relationships between P:A ratios and any of the density or secondary production variables. For October, high and low lifespan estimates of crab secondary production (high and low $F_{1,18}=4.911, \mathrm{p}=0.040$ ) and low lifespan estimates for total decapod secondary production $\left(F_{1,18}=5.743, \mathrm{p}=0.028\right)$ each had a significant negative relationship with $\mathrm{P}$ :A ratios.

\section{DISCUSSION}

Large-scale sampling efforts such as ours, across a range of naturally occurring seagrass patches in conjunction with ASU experiments, are rare, and studies that have been done have failed to produce consistent conclusions regarding the role of habitat fragmentation (Irlandi 1997, Hovel \& Lipcius 2001). This study is no exception: habitat fragmentation per se did influence abundances and secondary production estimates, but results were inconsistent and varied by species, location and date. In natural seagrass beds, the degree of isolation, area and perimeter:area ratios each had a minor influence on faunal distributions, while measures of seagrass biomass and epiphyte biomass played no significant role for decapods and fishes. In addition, linear regressions of secondary production estimates against these variables revealed in no significant relationships.

Table 4. Secondary production estimates $\left(\mathrm{g}\right.$ AFDW $\mathrm{m}^{-2}$ ) of crab and shrimp populations that colonized Halodule wrightii artificial seagrass units in Grand Bay, Alabama. Further details as for Table 3

\begin{tabular}{|c|c|c|c|c|}
\hline \multirow{2}{*}{$\begin{array}{l}\text { Organism, } \\
\quad \text { lifespan (yr) }\end{array}$} & \multicolumn{2}{|c|}{ Stellate } & \multicolumn{2}{|c|}{ Circular } \\
\hline & Large & Small & Large & Small \\
\hline \multicolumn{5}{|l|}{ Jul 9} \\
\hline \multicolumn{5}{|l|}{ Crabs } \\
\hline 3 & 6.14 & 3.73 & 6.57 & 3.39 \\
\hline 1 & 14.14 & 8.60 & 15.15 & 7.81 \\
\hline \multicolumn{5}{|l|}{ Shrimps } \\
\hline 0.42 & 21.50 & 13.35 & 22.94 & 11.71 \\
\hline 0.17 & 42.75 & 26.54 & 45.62 & 23.28 \\
\hline \multicolumn{5}{|l|}{ Decapods } \\
\hline High & 48.89 & 30.27 & 52.19 & 26.67 \\
\hline Low & $35.64^{\mathrm{a}}$ & $21.95^{\mathrm{b}}$ & $38.09^{a}$ & $19.52^{\mathrm{b}}$ \\
\hline \multicolumn{5}{|l|}{ Fishes } \\
\hline 1.5 & 1.72 & 9.64 & 1.61 & 3.42 \\
\hline 0.5 & 13.32 & 74.59 & 12.49 & 26.45 \\
\hline \multicolumn{5}{|l|}{ Aug 29} \\
\hline \multicolumn{5}{|l|}{ Crabs } \\
\hline 3 & 6.91 & 9.09 & 6.80 & 5.89 \\
\hline 1 & 15.94 & 20.96 & 15.68 & 13.57 \\
\hline \multicolumn{5}{|l|}{ Shrimps } \\
\hline 0.42 & 9.14 & 13.97 & 16.22 & 10.28 \\
\hline 0.17 & 18.17 & 27.79 & 32.25 & 20.44 \\
\hline \multicolumn{5}{|l|}{ Decapods } \\
\hline High & 25.08 & 36.88 & 39.06 & 26.33 \\
\hline Low & 25.07 & 34.93 & 31.90 & 23.85 \\
\hline \multicolumn{5}{|l|}{ Fishes } \\
\hline 1.5 & $1.65^{\mathrm{a}}$ & $2.50^{\mathrm{a}}$ & $1.13^{b}$ & $0.16^{\mathrm{b}}$ \\
\hline 0.5 & $12.78^{\mathrm{a}}$ & $19.34^{\mathrm{a}}$ & $8.72^{\mathrm{b}}$ & $1.21^{\mathrm{b}}$ \\
\hline \multicolumn{5}{|l|}{ Oct 24} \\
\hline \multicolumn{5}{|l|}{ Crabs } \\
\hline 3 & $7.32^{\mathrm{a}}$ & $2.52^{\mathrm{b}}$ & $7.10^{\mathrm{a}}$ & $2.74^{\mathrm{b}}$ \\
\hline 1 & $16.88^{\mathrm{a}}$ & $5.8^{\mathrm{b}}$ & $16.37^{\mathrm{a}}$ & $6.32^{\mathrm{b}}$ \\
\hline \multicolumn{5}{|l|}{ Shrimps } \\
\hline 0.42 & 8.57 & 5.59 & 11.97 & 3.97 \\
\hline 0.17 & 17.04 & 11.12 & 23.80 & 7.90 \\
\hline \multicolumn{5}{|l|}{ Decapods } \\
\hline High & $24.36^{\mathrm{a}}$ & $13.64^{\mathrm{b}}$ & $30.90^{\mathrm{a}}$ & $10.64^{\mathrm{b}}$ \\
\hline Low & $25.45^{\mathrm{a}}$ & $11.4^{\mathrm{b}}$ & $28.34^{\mathrm{a}}$ & $10.29^{b}$ \\
\hline \multicolumn{5}{|l|}{ Fishes } \\
\hline 1.5 & 3.98 & 0.85 & 1.51 & 1.19 \\
\hline 0.5 & 30.85 & 6.57 & 11.67 & 9.25 \\
\hline
\end{tabular}


In general, distance between patches seemed to have the most influence on fish and blue crab densities in naturally occurring seagrass meadows. We propose that for blue crabs, increased isolation of seagrass patches may result in decreased densities by reducing the post-settlement movement of crabs both into and out of the seagrass patch. Because of increased predation risks when crossing unstructured seafloor among seagrass beds (Orth et al. 1984, Micheli \& Peterson 1999), juvenile blue crabs may have little success in immigrating from larger source areas to the patch, or emigrating from the isolated patch to more suitable habitats. The coupling of these 2 processes may be responsible for the decreased abundances in isolated patches. Hovel \& Lipcius (2002) found that, for blue crabs, increased mortality was more clearly related to both decreased shoot density in large isolated patches and increased conspecific predation in small isolated patches than to the degree of patch isolation. To our knowledge, ours is the first study to demonstrate instances of a relationship between degree of isolation and blue crab densities in the Gulf of Mexico.

In the present study, P:A ratios explained significant amounts of variation in some mud crab, blue crab and caridean densities as well as crab secondary production. Perimeter:area ratios are a useful, and underutilized, measure of habitat fragmentation that combine patch shape and size into a single metric. This metric can be utilized at both the landscape scale and patch scale, although, methodologies vary between the two. At the landscape scale, mean perimeter:area ratios are used (Schumaker 1996), but at the patch level we utilized individual patch measurements in our regression analyses. The P:A ratio is a unique measurement of patch characteristics that can reduce the possibility of correlation between area or perimeter and other unmeasured variables and can be independent of either area or perimeter. As a result, the new value is not able to be back-transformed to estimate perimeter or area (Schumaker 1996). Thus, some information pertaining to both patch area and perimeter are lost, but the possibility of correlation among variables is reduced. However, use of P:A ratios does not mean that patch quality or isolation can be ignored. It is critical that these also be included because they are important aspects of habitat fragmentation (Andrén 1994, Farhig 1997, Bender et al. 1998).

Does the apparent lack of consistency among locations, species and sample periods suggest that habitat fragmentation per se is not structuring communities? Our data and analyses do suggest this, although the answer is not simple. Our analysis employed $\log _{10}$ transformation of non-linear data in order to utilize linear regression techniques. Many terrestrial relationships resulting from habitat fragmentation have been
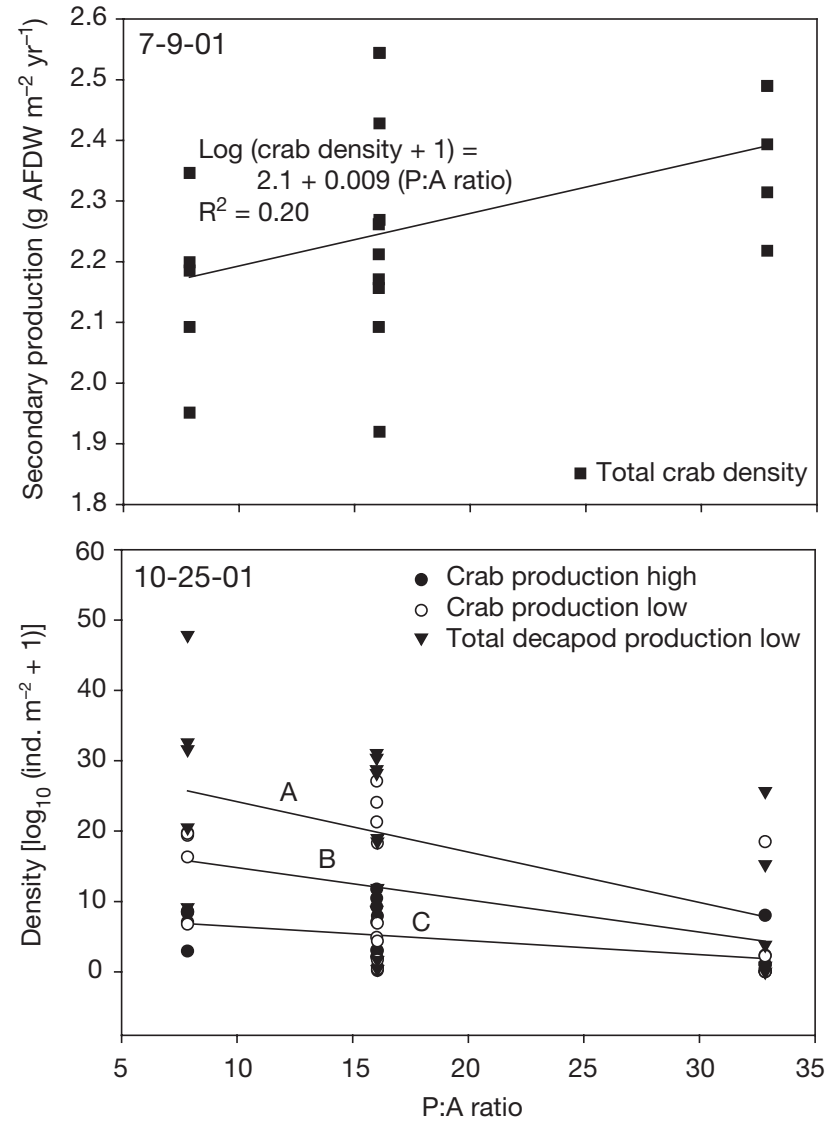

Fig. 8. Significant $(p<0.05)$ linear regressions for density and production estimates versus P:A ratios for ASUs in Grand Bay. Regression equations for October 25, $2001=\mathrm{A}$ : decapod production $(\mathrm{low})=31.3-0.72 \mathrm{P}: \mathrm{A}, \mathrm{r}^{2}=0.24 ; \mathrm{B}$ : crab production (low) $=19.4-0.458\left(\mathrm{P}: \mathrm{A}\right.$ ratio), $\mathrm{r}^{2}=0.21 ; \mathrm{C}$ : crab production (high) $=8.41-0.20 \mathrm{P}: \mathrm{A}, \mathrm{r}^{2}=0.21$, where $\mathrm{P}: \mathrm{A}=$ perimeter: area ratio

shown to be non-linear, usually in conjunction with a threshold level of patch size (With \& Crist 1995). The significant linear relationships that resulted after the $\log _{10}$ transformation does suggest that non-linear effects of fragmentation may be at work here; however, we felt it advisable to restrict analyses to simple analytical methods. In addition, we acknowledge that the scale of this study may have also have influenced our conclusions (Stephens et al. 2004, Ribas et al. 2005). Habitat fragmentation is by definition a landscape issue, and we have utilized patch-level patterns to draw inferences. This means that although scaling up results is not uncommon, our results must be applied with caution until they can be verified on a landscape level. In a review, Andrén (1994) noted that although the mechanisms at work varied, models using individuals rather than local populations to examine the effects of habitat fragmentation on bird and mammals reached results similar to those of landscapescale metapopulation models. 
Despite these caveats, we believe that habitat fragmentation per se is not of critical importance within these seagrass meadows because of the nature of the organisms that inhabit them. Excluding some of the fishes, the organisms that we examined could all be considered habitat generalists that migrate to some extent, 2 traits that can reduce the impact of habitat fragmentation (Bender et al. 1998). An animal that is a habitat generalist does not discriminate between the edge of a patch and the interior (Andrén 1994). Mud crabs from Big Lagoon were the only species that were area-sensitive, and may be the only species of interest that could not be labeled a habitat generalist. More crabs were collected in the interior of a patch than the exterior and were found on larger ASUs more than on smaller ASUs. This may be have been the result of an interaction between flow dynamics and the settlement of detritus on larger patches, a source of food for mud crabs (Williams 1984). According to Bell et al. (1995), smaller patches accumulate less drift algae than larger patches, and we suggest that a similar process with detrital material may have been at work here. In addition, as noted above, the ability to migrate is also common in these systems. Seagrasses in Big Lagoon and Grand Bay are ephemeral, dying back in the cold months and growing during the warm months (M. W. Johnson pers. obs.), resulting in most organisms migrating either offshore, to shallow tidal creeks, or to deeper bay waters.

The influence of patch size and patch shape on densities and secondary production was most obvious for decapods within ASUs and illustrates what may occur when mean patch size is reduced without loss of habitat. In Grand Bay, large patches had higher estimated secondary production for crabs, shrimps and combined decapods in June and October. In June, crab abundance was positively related to $\mathrm{P}: \mathrm{A}$ ratio and more crabs were collected on smaller than larger ASUs. Increased recruitment to smaller habitats has been demonstrated in multiple types of habitats (Sousa 1984, Bell et al. 1987, Worthington et al. 1992, McNeill \& Fairweather 1993, Thrush et al. 1996). In addition, conspecific predation by larger blue crabs can produce decreases in blue crab populations and may contribute to crab predation in ASUs (Hines et al. 1990, Mansour 1992, Moksnes et al. 1997). In Big Lagoon, secondary production estimates for large ASUs were higher for crabs in June and both shrimps and total decapods in August. Mean densities of blue crabs were higher for small ASUs in August, and caridean densities were larger for large ASUs in August and October. This suggests that, in Big Lagoon, either crabs do not respond to patch dynamics or that post-settlement processes (i.e. predation) are masking responses. Grass shrimp, however, may settle, migrate or grow faster on larger
ASUs. Caridean shrimp densities in seagrasses have been attributed to predator avoidance rather than increased food availability (Coen et al. 1981), suggesting that the increased amount of structure in larger ASUs may decrease predation rates on caridean shrimp (see Orth et al. 1984). In addition, caridean shrimps and blue crabs are highly mobile organisms whose distributions can vary daily (Howard 1985, Kneib \& Wagner 1994). This leads us to believe that post-settlement processes have a major influence on abundance and secondary production estimates.

Comparisons with other habitat fragmentation studies must be made with caution. Impacts of habitat fragmentation may vary with the scale of the experiment (Stephens et al. 2004, Ribas et al. 2005), species of interest, and the terms used to describe patch size (e.g. large and small). Latitudinal patterns in habitat fragmentation may also exist and must be noted in any comparisons of multiple studies. Habitat-fragmentation in seagrass beds along the mid-Atlantic and Pacific coasts (Irlandi 1996, 1997, Eggleston et al. 1998, 1999, Irlandi et al. 1999, Hovel \& Lipcius 2001, 2002, Hovel 2003) seems to have a stronger influence over organisms than in the Gulf of Mexico (Bologna \& Heck 2000, Bell et al. 2001, 2002, present study). To be more specific, within the northern Gulf of Mexico, Bologna \& Heck (2000) and the present study found more of an impact than studies carries out farther south (Bell et al. 2001, 2002). The exact reasons for this are unknown; however, in general there is an increase in tidal movement and decrease in trophic complexity with increasing latitude. More tidal movement may allow greater movement of organisms among patches and increase passive food delivery, thus increasing the importance of edge (Fonseca et al. 1982). Potentially, the impact of flow dynamics on settlement and recruitment may also increase with stronger tidal flow. It is possible that by decreasing the number of species within a system, the interaction between an organism and its habitat may also be altered. In a recent study, habitat preference by grass shrimp was influenced by the number of trophic levels within a mesocosm system (Johnson \& Heck 2005). Much more effort is needed to understand the role that latitude (and longitude) play.

In conclusion, we have demonstrated that at the scale of this study, habitat fragmentation per se did not consistently influence densities of seagrass-associated decapods and fishes in Big Lagoon, Florida or Grand Bay, Alabama. However, the degree of isolation of a patch may exert some control over organism densities; also, as patches got smaller, P:A ratios seemed to increase in importance. Our study is unique because we found no significant covariation between patch size and above-ground biomass in naturally occurring seagrass beds. Combined with the ASU experiments, we 
were able to examine the role of habitat fragmentation without confounding effects of habitat loss, a common by-product of habitat fragmentation (Andrén 1994, Fonseca \& Bell 1998). In each study location, intrapatch location played a minor role in explaining the densities of decapods and fishes, suggesting that edge effects in marine systems may not play as extensive a role in determining the kind and abundance of organisms as suggested for terrestrial systems (Yahner 1988). Ultimately, habitat fragmentation may be most detrimental to seagrass-associated animals when it leads to large-scale losses of the area covered by seagrasses.

Acknowledgements. Funding for the project was provided by EPA Grant No. GR 828779-01-0 and by a grant from the Alabama Center for Estuarine Studies (ACES). We thank D. Kilbane, S. C. Davis, and the multiple interns, REUs, and graduate students that helped make this study possible. In addition, we thank the 1 known and 2 anonymous reviewers for their comments and opinions. M.W.J. thanks foremost K. Johnson for her support and help with this project. This is contribution \#366 of the Dauphin Island Sea Laboratory.

\section{LITERATURE CITED}

Andrén H (1994) Effects of habitat fragmentation on birds and mammals in landscapes with different proportions of suitable habitat: a review. Oikos 71:355-366

Bauer RT (1989) Continuous reproduction and episodic recruitment in nine shrimp species inhabiting a tropical seagrass meadow. J Exp Mar Biol Ecol 127:175-187

Bell JD, Westoby M, Steffe AS (1987) Fish larvae settling in seagrass: do they discriminate between beds of different leaf density? J Exp Mar Biol Ecol 111:133-144

Bell SS, Hall M, Robbins BD (1995) Toward a landscape approach in seagrass beds: using macroalgal accumulation to address questions of scale. Oecologia 104:163-168

Bell SS, Brooks R A, Robbins BD, Fonseca MS, Hall MO (2001) Faunal response to fragmentation in seagrass habitats: implications for seagrass conservation. Biol Conserv 100: 115-123

Bell SS, Hall MO, Soffian S, Madley K (2002) Assessing the impact of boat propeller scars on fish and shrimp utilizing seagrass beds. Ecol Appl 12:206-217

Bender DJ, Contresas TA, Fahrig L (1998) Habitat loss and population decline: a meta-analysis of patch size effect. Ecology 79:517-533

Bologna PAX (1998) The effects of seagrass habitat architecture on associated fauna. $\mathrm{PhD}$ dissertation, University of South Alabama, Mobile, AL

Bologna PAX, Heck KL Jr (1999) Differential predation and growth rates of bay scallops within a seagrass habitat. J Exp Mar Biol Ecol 239:299-314

Bologna PAX, Heck KL Jr (2000) Impacts of seagrass habitat architecture on bivalve settlement. Estuaries 23:449-457

Coen LD, Heck KL Jr, Abele LG (1981) Experiments on competition and predation among shrimps of seagrass meadows. Ecology 62:1484-1493

Debinski DM, Holt RD (2000) Review: a survey and overview of habitat fragmentation experiments. Conserv Biol 14: 342-355

Duarte CM (1995) Submerged aquatic vegetation in relation to different nutrient regimes. Ophelia 41:37-112

Eggleston DB, Etherington LL, Elis WE (1998) Organism response to habitat patchiness: species and habitatdependent recruitment of decapod crustaceans. J Exp Mar Biol Ecol 223:111-132

Eggleston DB, Elis WE, Etherington LL, Dahlgren CP, Posey $\mathrm{MH}$ (1999) Organism responses to habitat fragmentation and diversity: habitat colonization by estuarine macrofauna. J Exp Mar Biol Ecol 236:107-132

Fahrig L (1997) Relative effects of habitat loss and fragmentation on population extinction. J Wildl Manag 61:603-610

Fahrig L (1998) When does fragmentation of breeding habitat affect population survival? Ecol Model 105:273-292

Fonseca MS, Bell SS (1998) Influence of physical setting on seagrass landscapes near Beaufort, North Carolina, USA. Mar Ecol Prog Ser 171:109-121

Fonseca MS, Fisher JS, Zieman JC, Thayer GW (1982) Influence of the seagrass, Zostera marina L., on current flow. Estuar Coast Shelf Sci 15:351-364

Fonseca MS, Kenworthy WJ, Thayer GW (1998) Guidelines for the conservation and restoration of seagrasses in the United States and adjacent waters. NOAA Coastal Ocean Program Office, Silver Spring, MD

Heck KL Jr, Able KW, Roman CT, Fahay MP (1995) Composition, abundance, biomass, and production of macrofauna in a New England estuary: comparisons among eelgrass meadows and other nursery habitats. Estuaries 18: 379-389

Hines AH, Haddon AM, Wiechert LA (1990) Guild structure and foraging impact of blue crabs and epibenthic fish in a subestuary of Chesapeake Bay. Mar Ecol Prog Ser 67: 105-126

Hovel KA (2003) Habitat fragmentation in marine landscapes: relative effects of cover and configuration on juvenile crab survival in California and North Carolina seagrass beds. Biol Conserv 110:401-412

Hovel KA, Lipcius RN (2001) Habitat fragmentation in a seagrass landscape: patch size and complexity control blue crab survival. Ecology 82:1814-1829

Hovel KA, Lipcius RN (2002) Effects of seagrass habitat fragmentation on juvenile blue crab survival and abundance. J Exp Mar Biol Ecol 271:75-98

Hovel KA, Fonseca MS, Myer DL, Kenworthy WJ, Whitfield PE (2002) Effects of seagrass landscape structure, structural complexity and hydrodynamic regime on macrofaunal densities in North Carolina seagrass beds. Mar Ecol Prog Ser 243:11-24

Howard RK (1985) Measurements of short-term turnover of epifauna within seagrass beds using an in situ staining method. Mar Ecol Prog Ser 22:163-168

Irlandi EA (1996) The effect of seagrass patch size and energy regime on growth of an infaunal bivalve. J Mar Res 54: $1-26$

Irlandi EA (1997) Seagrass patch size and survivorship of an infaunal bivalve. Oikos 78:511-518

Irlandi EA, Orlando BA, Ambrose WG Jr (1999) Influence of seagrass habitat patch size on growth and survival of juvenile bay scallops, Argopecten irradians concentricus (Say). J Exp Mar Biol Ecol 235:21-43

Johnson MW, Heck KL Jr (2005) The role of habitat fragmentation in the structure and function of seagrass ecosystems in the northern Gulf of Mexico. MASGP 04-049, Mississippi-Alabama Sea Grant Consortium, Ocean Springs, MS

Kneib RT, Wagner SL (1994) Nekton use of vegetated marsh habitats at different stages of tidal inundation. Mar Ecol Prog Ser 106:227-238

Larkum AW, den Hartog C (1989) Evolution and biogeo- 
graphy of seagrasses. In: Larkum WD, McComb A, Sheppard SA (eds) Biology of seagrasses: a treatise on the biology of seagrasses with special reference to the Australia region. Elsevier Science, Amsterdam, p 112-156

Mansour RA (1992) Foraging ecology of the blue crab, Callinectes sapidus Rathbun, in the lower Chesapeake Bay. College of William and Mary, Gloucester Point, VA

McNeill SE, Fairweather PG (1993) Single large or several small marine reserves? An experimental approach with seagrass fauna. J Biogeogr 20:429-440

Micheli F, Peterson CH (1999) Estuarine vegetated habitats as corridors for predator movements. Conserv Biol 4:869-881

Moksnes PO, Lipcius RN, Pihl L, van Montfrans J (1997) Cannibal-prey dynamics in young juveniles and postlarvae of the blue crab. J Exp Mar Biol Ecol 215:157-187

Orth RJ, van Montfrans J (1987) Utilization of a seagrass meadow and tidal marsh creek by blue crabs Callinectes sapidus. 1. Seasonal and annual variations in abundance with emphasis on post-settlement juveniles. Mar Ecol Prog Ser 41:283-294

Orth RJ, Heck KL Jr, van Montfrans J (1984) Faunal communities in seagrass beds: a review of the influence of plant structure and prey characteristics on predator-prey relationships. Estuaries 7:339-350

Ovaskainen O (2002) Long-term persistence of species and the SLOSS problem. J Theor Biol 218:419-433

Peintinger M, Bergamini A, Schmid B (2003) Species-area relationships and nestedness of four taxonomic groups in fragmented wetlands. Basic Appl Ecol 4:385-394

Peterson CH, Grabowski JH, Powers SP (2003) Estimated enhancement of fish production resulting from restoring oyster reef habitat: quantitative evaluation. Mar Ecol Prog Ser 264:249-264

Polis GA, Anderson WB, Holt RD (1997) Towards an integration of landscape and food web ecology: the dynamics of spatially subsidized food webs. Annu Rev Ecol Syst 28: 289-316

Ribas CR, Sobrinho TG, Schoereder JH, Sperber CF, LopesAndrade C, Soares SM (2005) How large is large enough for insects? Forest fragmentation effects at three spatial scales. Acta Oecol 27:21-41

Robbins BD, Bell SS (1994) Seagrass landscapes: a terrestrial approach to the marine subtidal environment. Trends Ecol Evol 9:301-304

Robertson AI (1979) The relationship between annual production:biomass ratios and lifespans for marine macrobenthos. Oecologia 38:193-202

Sargent FJ, Leary TJ, Crewz D, Truer CR (1995) Scarring of Florida's seagrasses: assessment and management

Editorial responsibility: Ronald Karlson (Contributing Editor), Newark, Delaware, USA options. FMRI Technical Report TR-1, Florida Department of Environmental Protection, St. Petersburg, FL

Schumaker NH (1996) Using landscape indices to predict habitat connectivity. Ecology 77:1210-1225

Sousa W (1984) Intertidal mosaics: patch size, propagule availability, and spatially variable patterns of succession. Ecology 65:1918-1935

SPSS (Subprogram of Statistical Package for Social Sciences) (2000) SPSS for Windows. Version 11.0. SPSS, Chicago, IL

Stephens SE, Koons DN, Rotella JJ, Willey DW (2004) Effects of habitat fragmentation on avian nesting success: a review of the evidence at multiple spatial scales. Biol Conserv 115:101-110

Stutes JP (2000) The relative importance of vertebrate and invertebrate grazing on seagrass epiphytes in the northern Gulf of Mexico: an experimental assessment. MSc, University of South Alabama, Mobile, AL

Thrush SF, Whitlatch RB, Pridmore RD, Hewitt JE, Cummings VJ, Wilkinson MR (1996) Scale-dependent recolonization: the role of sediment stability in a dynamic sandflat habitat. Ecology 77:2472-2487

Trzcinski MK, Fahrig L, Merriam G (1999) Independent effects of forest cover and fragmentation on the distribution of forest breeding birds. Ecol Appl 9:586-593

Turner SJ, Hewitt JE, Wilkinson MR, Morrisey DJ, Thrush SF, Cummings VJ, Funnell G (1999) Seagrass patches and landscapes: the influence of wind-wave dynamics and hierarchical arrangements of spatial structure on macrofaunal seagrass communities. Estuaries 22:1016-1032

Valentine JF, Heck KL Jr (1993) Mussels in seagrass meadows: their influence on macroinvertebrate abundance and secondary production in the northern Gulf of Mexico. Mar Ecol Prog Ser 96:63-74

Villard MA, Trzcinski MK, Merriam G (1999) Fragmentation effects on forest birds: relative influence of woodland cover and configuration on landscape occupancy. Conserv Biol 13:774-784

Waters TF (1977) Secondary production in inland waters. Adv Ecol Res 10:91-164

Williams AB (1984) Shrimps, lobsters, and crabs of the Atlantic coast of the eastern United States, Maine to Florida. Smithsonian Institution Press, Washington DC

With KA, Crist TO (1995) Critical thresholds in species' responses to landscape structure. Ecology 76:2446-2459

Worthington DG, Ferrell DJ, McNeill SE, Bell JD (1992) Effects of shoot density of seagrass on fish and decapods: are they evident over large spatial scales? Mar Biol 112: 139-146

Yahner RH (1988) Changes in wildlife communities near edges. Conserv Biol 2:333-339

Submitted: April 20, 2004; Accepted: June 21, 2005

Proofs received from author(s): December 9, 2005 